\title{
Review
}

\section{Experimental ecology: A key to understanding fish biology in the wild}

\author{
Marc Suquet $^{1, a}$, Marie-Joëlle Rochet ${ }^{2}$ and Jean-Louis Gaignon ${ }^{1}$ \\ ${ }^{1}$ Laboratoire Adaptation Reproduction Nutrition, IFREMER, BP 70, 29280 Plouzané, France \\ 2 Département Ecologie et Modèles pour l'Halieutique, IFREMER, BP 21105, 44311 Nantes Cedex 03, France
}

Received 23 December 2004; Accepted 8 September 2005

\begin{abstract}
Because of natural complexity, field studies are often inconclusive with regards to the ultimate cause of a given change observed in wild animal populations. As a consequence, there is scope to develop an Experimental Ecology Approach (EEA). In this paper, we favour the use of experimental ecology studies to evaluate the effects of environmental factors on fish biology. We identify the advantages of EEA: disentangling the effects of several factors and identifying their respective roles, generating artificial scenarios and increasing our capability to collect and analyse data. This study emphasises the constraints of this approach: fish biological performances may be altered by rearing conditions, by domestication and by the prevention of some behaviours. It also considers the extrapolation of experimental results with regard to the sea including the realism of experimental design and the constraints of scaling or extending the results to larger scales. We also propose some experimental ecosystems which are well adapted to the requirements of EEA and a careful selection of fish species which fit this approach very well. Atlantic Cod (Gadus morhua) is identified as a good candidate for experimental studies and we present examples of the contribution of EEA to the description and quantification of the effects of environmental factors in this species. We conclude by highlighting the respective contribution of field studies (describing a situation in the wild and suggesting some possible causes) and EEA (allowing an active investigation of phenomena and identifying their final causes).
\end{abstract}

Key words: Experimental ecology / Laboratory experiments / Environmental parameters / Field study / Cod

Résumé - Écologie expérimentale : une clef pour la compréhension de la biologie des poissons dans le milieu naturel. En raison de la complexité du milieu naturel, les études de terrain n'apportent souvent pas de conclusion définitive sur la cause d'un changement observé chez les populations sauvages d'animaux. C'est pourquoi, il est indispensable de mettre en place une approche en écologie expérimentale (AEE). Nous proposons le développement d'études d'écologie expérimentale afin de décrire l'effet de facteurs de l'environnement sur la biologie des poissons. Les principaux avantages de l'AEE sont la distinction de l'effet respectif des facteurs permettant d'identifier leur rôle indépendamment, la possibilité de générer des scénarios artificiels et l'amélioration de la collecte ou de l'analyse des données expérimentales. Les contraintes de cette approche sont soulignées : modifications des performances biologiques des poissons dues aux conditions d'élevage, à la domestication des animaux ou encore à la prévention de certains comportements tels que les migrations. Ce travail décrit les difficultés rencontrées lors de l'extrapolation des résultats expérimentaux au milieu naturel telles que la représentativité du dispositif expérimental et les contraintes observées lors du changement d'échelle. Nous proposons également différents écosystèmes expérimentaux adaptés aux objectifs de l'AEE et une sélection attentive d'espèces de poissons utilisées lors de ce type d'étude. La morue ayant été identifiée comme étant un bon candidat pour des travaux en écologie expérimentale, cet article met en évidence l'apport de l'AEE à la description et à la mesure de l'effet de facteurs de l'environnement sur cette espèce. Enfin, nous mettons en évidence l'apport complémentaire des études de terrain, décrivant une situation observée dans le milieu naturel et suggérant des causes possibles et de l'AEE, permettant une compréhension active du phénomène et l'identification de sa cause finale.

\footnotetext{
a Corresponding author: msuquet@ifremer.fr
} 


\section{Introduction}

Field studies in ecology are often inconclusive with regard to the ultimate cause of a given change due to the intricacy of environmental factors and the scarcity of appropriate data. This provides scope to develop experimental studies designed to investigate the effects of interacting environmental factors. Experimental ecology approach (EEA) could be defined as an experimental work carried out in laboratory or in the field in order to test hypothesis settled in the wild. By completing field observations, EEA helps to draw conclusions concerning the effects of some environmental factors on animal functions such as reproduction or growth. EEA is situated between mimicking the natural environment and using a small scale experimental design to control the effects of environmental factors (Ylönen and Wolff 1999). This approach uses experimental microcosms varying in size from test tubes to large tanks, thus reducing the complexity of the natural environment.

Designing experiments is fundamental to the advancement of ecology (Lawton 1995). In the marine environment, EEA is used in various fields such as coastal management (Castilla 2000), ecology of rocky intertidal habitats (Underwood 2000), stock enhancement (Kellison et al. 2003), fisheries management (Morgan et al. 1999; Rowe et al. 2004) or the effect of pollutants on resources (Aas et al. 2000). EEA has been conducted in a wide range of marine organisms, including: coral (Lesser 2004), deep sea tubeworms (Van Dover and Lutz 2004), phytoplankton (Spies and Parsons 1985), lobsters or crabs (Ojeda and Dearborn 1991; Whale 2003) and fish (Isaksson et al. 1994).

Brander (1996) highlighted the need for an experimental approach to fish, suggesting this method would help assess the effects of temperature on cod recruitment within the context of global warming. Large differences in the growth of cod stocks have been observed, which may be related either to environmental factors (e.g., food availability and temperature) or to genetic causes. According to Imsland and Jonsdottir (2002), it is necessary to rear cod from different populations in a controlled environment in order to estimate the respective effects of each factor.

Reviews devoted to experimental ecology studies are scarce. Underwood (1996) underscored the contribution of EEA to environmental problem solving, showing the massive increase in the use of experimental studies since 1965. The contribution of EEA to explaining stock recruitment relationships in crustaceans was reviewed by Whale (2003), focusing on the influence of competition, predation, cannibalism and movements on the demography of crabs and lobsters. EEA studies carried out to improve the understanding of the ecology of deep sea hydrothermal systems were reviewed by Van Dover and Lutz (2004). Then, the use of EEA in ecotoxicology was highlighted by Devauchelle (2002), showing that only $0.65 \%$ of 100000 commercial substances were tested in marine organisms.

This paper presents arguments in favor of developing experimental ecology studies in marine fish. It identifies the advantages and constraints of this approach. Methodological issues such as experimental design and selection of fish species for experimental studies are also considered. The contribution of experimental ecology to the description of the effect of environmental parameters on the biology of cod is highlighted. Finally, the problem of the extrapolation of experimental results to larger ecosystems is considered.

\section{The advantages of the experimental ecology approach}

Compared to field studies, EEA has several advantages related to the control of experimental conditions, namely i) partitioning the effects of factors, ii) choosing the range of environmental conditions and iii) improving sampling collection and analysis.

\subsection{Partitioning the effects of factors}

Disentangling the effects is the first advantage of the experimental ecology approach. Many factors vary concomitantly in the wild and may interact with observations of the studied ones. In this intricate field, it is not possible to distinguish between the role of these factors and concurrent effects. The experimental design reduces the natural complexity to just a variation in one or a set of studied factors. As a consequence, the confounding effects of interacting factors can be avoided in an experimental design. In the following two examples, the covariation of factors results in confounding effects whereby it is not possible to estimate the cause of the recorded effect: i) climate change may induce variations in cod recruitment because of the direct effect of temperature on spawner physiology and on fecundity or gamete quality but also because of the indirect effects of this parameter including plankton production (Sundby et al. 1994) or cannibalism (Nilssen et al. 1994), ii) teleost fish compensate for their mortality due to fishing by decreasing their age at maturity. This effect may be due to a population regulation mechanism but also to genetic changes induced by selection (Rochet et al. 2000). Since it has been not possible in both examples to disentangle the interacting causes by field observations, an experimental study would help to separate the role of these different factors and study their respective effect. Regarding climate change, the effect of water temperature may be studied by comparing spawning performances of breeders maintained at different water temperatures. Using a supplementary experimental design, survival and growth of cod larvae may be recorded when fed with different plankton regimes, varying in quantity and quality according to observations recorded in the wild. As a consequence, both direct and indirect effects of water temperature on cod recruitment could be quantified and compared using EEA.

\subsection{Choosing the range of environmental conditions}

In the wild, the variations in environmental parameters remain limited to the natural range. Furthermore, changes in these parameters are uncontrolled and difficult to predict. In contrast, in an experimental design, conditions which are different from the ones occurring in the wild can be mimicked, controlled and their effects assessed. A mean increase in sea surface temperature of $1.03{ }^{\circ} \mathrm{C}$ was recorded in the Bay of Biscay over the past century (Planque et al. 2003). Between 
1980 and 2000 , a 0.5 to $1{ }^{\circ} \mathrm{C}$ increase in sea water temperature was observed in this region at depths ranging from 0 to $-200 \mathrm{~m}$ (Vandermeirsch, unpublished results). The global warming hypothesis suggests a subsequent temperature rise of ocean waters. Temperature affects different functions in fish, including all aspects of reproduction (Van der Kraak and Pankhurst 1996). However, the assessment of these effects on reproductive performances in fish, especially under conditions suggested by the future scenario of climate changes, are not yet available. According to simulation models predicting future ocean warming (Hegerl and Bindoff 2005), artificial scenarios such as increasing water temperature can be generated in reduced controlled environments. Then, potential implications of these future changes on fish biology could be quantified using an experimental design.

\subsection{Improving sampling collection and analysis}

Compared to field studies, the experimental approach offers better means of data collection and analysis. At sea, the sampling period is limited to the duration of oceanographic surveys. Only restricted time-series are available. Therefore, the description of development stages or physiological cycles is partial, only covering the sampling period. In captivity, a more refined description of these cycles is possible because of the availability of breeders and multiple sampling opportunities. This is the case in pollack (Pollachius pollachius) where gametogenesis was described by sampling breeders kept in captivity, using parameters such as changes with time of oocyte diameter, histological examination and steroid concentration (Omnes et al. 2002). The description of gametogenesis is more difficult in rarely caught species such as wreckfish (Polyprion americanus) whereby adults are found in depths between 300 and $1000 \mathrm{~m}$. This study was carried out in captive adults kept in large volume tanks (Suquet et al. 2001).

Basic parameters such as food quality and quantity ingested or temperature experienced by fish in the wild are hardly ever measured. However, individual effects can be monitored during controlled experiments using tags or fish isolation. A complete picture of breeder physiological status including hormonal concentrations and blood composition can be recorded using laboratory facilities. These analytical and technical platforms are easier to use in a controlled experimental environment. The spawning performances of cod were individually monitored by keeping mature male-female pairs in small volume tanks. This showed female and egg batch rank effects accounting respectively for $35 \%$ and $26 \%$ of the total variance in egg diameter (Chambers and Waiwood 1996). The effects of trawl avoidance on the reproductive performances of cod were experimentally evaluated showing higher plasma cortisol levels, fewer courtships and a higher production of abnormal larvae (Morgan et al. 1999). Because of difficulties in age determination, European hake (Merluccius merluccius) growth may be underestimated from specimens collected in the wild. The growth rate observed in a tagging-recapture experiment was twice greater than that predicted by the model for this species (De Pontual et al. 2004). This suggests an overestimation of hake age. The determination of hake growth capacity could be improved using EEA by directly measuring otolith increments
Fig. 1. Features of two experimental ecosystems designed for Experimental Ecology Approach.

\begin{tabular}{|c|c|c|}
\hline & $\begin{array}{l}\text { Small controlled } \\
\text { tanks (relative size } \\
\text { or number) }\end{array}$ & $\begin{array}{l}\text { Mesocosm } \\
\text { (relative size } \\
\text { or number) } \\
\end{array}$ \\
\hline Enclosure volume & Small & Large \\
\hline Fish density & High & \\
\hline $\begin{array}{l}\text { Artificial } \\
\text { management }\end{array}$ & High & Low \\
\hline $\begin{array}{l}\text { Environmental } \\
\text { control }\end{array}$ & Low & High \\
\hline Fish behaviour & Low & High \\
\hline Factors interaction & Low & High \\
\hline $\begin{array}{l}\text { Extrapolation } \\
\text { to the wild }\end{array}$ & Low & High \\
\hline
\end{tabular}

and the growth rate of captive hakes fed ad libitum and exposed to an annual cycle of water temperature met in the wild by this species. Furthermore, the effects of some environmental factors on otolith growth pattern could be assessed in an experimental design.

\section{Tools required for the experimental ecology approach}

There is a large number of i) experimental ecosystems but also ii) fish species which could be candidates for EEA.

\subsection{Selecting an experimental ecosystem}

Compared to the wild, experimental ecology studies use reduced ecosystems. Two types of ecosystems can be used, depending on research requirements (Fig. 1).

Firstly, experimental studies can be carried out in small to medium volume $\left(0.5-15 \mathrm{~m}^{3}\right)$ tanks and fish can be kept at high stocking density. In this type of system, environmental (temperature, light intensity, light duration, salinity, etc.) and rearing factors (food quantity and quality, fish density, sexratio, etc.) are controlled. As a consequence, uncontrolled interaction between factors is limited. This system can be used for a mono factor experimental design in which the effect of different levels of a single factor is assessed: increasing temperature from 8 to $12{ }^{\circ} \mathrm{C}$ during the spawning period of the pollack (Pollachius pollachius) decreased the total number of released eggs by $96 \%$ and the number of viable eggs by $98 \%$ 
(Suquet et al. 2005). Examining the effects of multiple parameters seems more difficult due to the combination of factors and levels which rapidly increase the number of experimental conditions. However, a factorial fractional design can also be used (Kobilinsky 1997). This design, previously used in industry, decreases the number of studied factor combinations by selecting a fraction of the treatment combinations required for the complete factorial experiment. In the wild, this was used to estimate predation mortality in the Georges Bank fish community (Tsou and Collie 2001). This method has rarely been used in experimental design and, to our knowledge, never in the case of EEA. A fractional factorial design has been successfully used during screening experiments in the cryopreservation of milt of two cyprinid species, allowing the main and minor factors to be separated (Babiak et al. 2000). Since they are kept in a homogeneous environment, fish maintained in controlled experimental designs cannot select among different conditions. Therefore, this system constrains animal behaviour. Then, directly extrapolating results to the wild is not recommendable because this experimental system is highly simplified.

Secondly, mesocosms can also be used in experimental ecology studies: fish are kept at low density, in large $\left(15-1000 \mathrm{~m}^{3}\right)$ tanks or ponds and food is from both endogenous (planctonic blooms) and exogenous origins (Divanach and Kentouri 2000). Compared to small volume tanks, the mesocosm technique provides a host of possible preferrenda in terms of environmental conditions. As a consequence, animal behaviour is less constrained in mesocosms. The effects of water temperature, light intensity and wind speed on seabass (Dicentrarchus labrax) behaviour were investigated in large ponds $\left(200 \mathrm{~m}^{3}\right)$, using acoustic telemetry techniques (Bégout Anras and Lagardère 1998). Fish position was determined with an accuracy of $20 \mathrm{~cm}$. The swimming activity (trajectories, space utilisation and activity rhythms) was affected by these parameters. Such results could not be precisely assessed in the wild. Changes with time in physical parameters, chlorophyll, nutrient and plankton concentrations were assessed in $40 \mathrm{~m}^{3}$ enclosures in the presence or absence of a predator (sea bream, Sparus aurata larvae) (Pitta et al. 1997). In cod, this design was successfully used to estimate environmental and maternal effects on variability in length and growth of larvae and juveniles (Clemmesen et al. 2003). Then, mesocosms better mimic wild ecosystems because of their less constraining captivity conditions. Thus, direct extrapolation of experimental results to the wild is more justified, compared to small volumes controlled tanks.

\subsection{Selecting fish species}

In order to improve the development of EEA, fish species candidates for these studies must be selected according to some complementary aspects, using a process similar to the one implemented for new species in aquaculture (Quemener et al. 2002).

Firstly, a thorough knowledge of the biology and rearing practices of the selected species must be available because they are maintained in captivity. This is the case for cod whereby 10000 scientific publications are at present available in the Aquatic Sciences and Fisheries Abstracts (ASFA) base. However, only 2000 scientific publications refer to hake and, to our knowledge, none of them contains results about rearing experiments. Cod farming is expanding (Adoff et al. 2002) providing an increasing number of efficient rearing techniques because there is much greater knowledge regarding its biology and because landings have decreased dramatically.

Secondly, there is great concern about overfished species which show a decline in biomass and recruitment and a better knowledge of their biology could prove beneficial. It is essential to appreciate the main factors determining recruitment strength in order to achieve stock recovery. In this respect, Gadiformes such as cod or hake are species of interest for experimental ecology because of their recent collapse in world fisheries (cod: from 4 million t in 1968 to $900000 \mathrm{t}$ in 2001; hake: from $135000 \mathrm{t}$ in 1985 to $58000 \mathrm{t}$ in 2001; FAO 2001).

Thirdly, some scientific questions may concern a limited number of species. This is the case when the effects of environmental changes on the reproductive traits of fish are studied. Compensation strategies in the face of overfishing differ between fish species. Compensation is less efficient in Clupeiformes compared to Gadiformes and Perciformes because it mainly changes fecundity in response to increased adult mortality but does not act on age and length at maturity as observed in the former species (Rochet 2000). Fish species which are more resilient to overfishing must be selected to assess a compensation strategy. This is the case of cod which compensates for overfishing by implementing a density dependant growth, namely by decreasing their age at maturity and egg diameter, and by increasing their size at maturity and fecundity.

Cod is highly sensitive to environmental changes (Brander 1996), its fisheries have collapsed and overfishing of this species is compensated by a well marked compensation strategy (Rochet 2000). As a consequence, cod is considered as a good candidate for experimental ecology and EEA can help to understand and evaluate the effect of these different process. Cod candidature to EEA is sustained by its thoroughly understood biology and well controlled maintenance techniques

\section{Experimental ecology studies in cod}

The effects of environmental factors on cod biology have been widely studied. Many studies have been carried out in the wild. After summarizing the effects of environmental parameters on wild cod populations, three examples of EEA studies are reported in the following paragraphs, describing the contribution of EEA in studying these changes, in identifying their cause and quantifying their effects. These three cases are i) a single factor study: effect of food quantity on spawning performances, ii) a two-factor study: effect of salinity and oxygen on egg survival and iii) a range test: effect of water temperature on the growth rate.

\subsection{A single factor study: Effect of food quantity on spawning performances}

Trophic conditions may have a direct effect on cod reproduction. In the wild and in the early 1990 s, low prespawning and postspawning condition factors $\left(K=100 \mathrm{~W} \times \mathrm{L}^{-3}\right.$ 
(i.e. somatic Weight, fork Length)), low energy reserves but also reduced fecundities were recorded in wild females in the Northern Gulf of St Lawrence (Lambert and Dutil 2000).

In experimental conditions, the decline in energy reserves was monitored, showing that unfed cod were at an increased risk of mortality when their condition factor values were below 0.60 (Lambert and Dutil 1997). Compared to female cod with a poor Fulton condition factor $(K=0.5)$, the number of eggs released was three to seven fold higher in females with a high condition factor $(K=0.8-0.9)$. Furthermore, postspawning energy losses were proportionally higher in poor condition females, ranging from $25-40 \%$ compared to $5-25 \%$ in females with a high condition factor (Lambert and Dutil 2000). Correlations have been reported between female condition and egg size but also between egg size and subsequent performances of larvae such as survival, successful development of a swimbladder and specific growth rate (Marteinsdottir and Begg 2002). These experimental studies confirmed and quantified the effects of the environmental conditions deterioration on the collapse of the Gulf of St Lawrence cod stock and its failure to recover despite fishery closure. This was impossible in the wild where correlations between these elements cannot be reported in a same breeder.

\subsection{A two-factor study: Effect of salinity and oxygen on egg survival}

A high variability was reported in Baltic cod catches, decreasing from $450000 \mathrm{t}$ in 1984 to only $40000 \mathrm{t}$ in 1993 (Pickova et al. 2000). Higher landings were observed after major inflows of saline water to the Baltic sea, improving spawning conditions due to an increase in salinity and oxygen concentration.

Experimental studies confirmed that egg survival was greatly affected by salinity and oxygen concentration, showing a mortality rate of about $99 \%$ of eggs at low values for both parameters (Nissling 1994). The causes of reproductive problems in the Baltic sea cod may include other factors such as environmental pollution resulting from human activity (Pickova et al. 2000). However, EEA has confirmed the strong impact of salinity-oxygen interactions on cod egg survival, suggested in the wild. This was not recommendable in the wild because many other factors co-varying with Baltic salinity.

\subsection{A range test: Effect of water temperature on the growth rate}

Cod lives within a wide range of water temperatures from below 0 to $20{ }^{\circ} \mathrm{C}$. Size at particular age varies substantially: from $0.6 \mathrm{~kg}$ in Labrador to $7.2 \mathrm{~kg}$ in the Celtic sea at 4 years old (Brander 1996). This variability could be attributed to water temperature but also to genetic differences among populations.

In laboratory experiments, the effect of water temperature was tested in cod collected on the southwestern coast of Iceland. As in many other fish species, optimal temperature for growth decreases with fish size: from $16^{\circ} \mathrm{C}$ for $2 \mathrm{~g} \operatorname{cod}$ to $7^{\circ} \mathrm{C}$ for $2000 \mathrm{~g}$ cod (Björnsson et al. 2001) or from $14.3^{\circ} \mathrm{C}$ for $50 \mathrm{~g}$ cod to $5.9^{\circ} \mathrm{C}$ for $5000 \mathrm{~g}$ cod (Björnsson and Steinarsson 2002). The growth rate of juveniles is more affected by temperature than that of larger cod. Furthermore, a stock specific difference in growth capacity has been reported: a higher daily weightspecific growth rate was recorded in Norwegian coastal cod larvae (14.4 to $22.3 \%$ day $^{-1}$ ) compared to those from northeastern Arctic ones (13.6-19.7\% day $^{-1}$ ) (Otterlei et al. 1999). Between two genetically-differing cod stocks, larvae from the Grand Banks grew faster than Gulf of Maine individuals at both 7 and $12{ }^{\circ} \mathrm{C}$ (Purchase and Brown 2000). In this third example, experimental studies confirmed and quantified the respective effects of environmental and genetic factors on cod growth. This was not possible in the wild because of the covariation of several factors (temperature, food quality and quantity, genetic origin...).

\section{The constraints of the experimental ecology approach}

EEA also has several drawbacks, namely i) rearing conditions, ii) fish domestication and iii) prevention of fish behaviour. These constraints must be taken into account when performing experimental ecology studies.

\subsection{Rearing conditions}

Rearing facilities offer conditions which can alter fish performances. An increase in stock density in tanks may result in lower food conversion or growth rate and an increase in fin erosion. These effects were observed even in rainbow trout (Oncorhynchus mykiss), an intensively farmed species which is considered to be tolerant to high stock densities (Ellis et al. 2002). The specific growth rate of cod fed ad libitum fell from $1.08 \%$ to $0.66 \%$ when stock density was raised from 2 to $40 \mathrm{~kg} \mathrm{~m}^{-3}$. These changes reflected a lower food intake assessed in high density condition (Lambert and Dutil 2001). Up to one-third of adult cod pairs isolated in small volume tanks showed signs of stress, resulting in irregular spawning intervals and low fertilisation rates (Kjesbu 1989). On the other hand, the fecundity of wild cod, maintained in captivity and fed with trash fish for up to three years, was twice that measured in wild free-living cod. This greater oocyte production in farmed fish was related to good nutrition provided in captivity (Wroblewski et al. 1999). As a consequence, rearing conditions may have a great effect on EEA results, either decreasing or increasing fish performances.

Keeping fish under poor rearing conditions of high stock density or inadequate food availability, enhances fish size heterogeneity (Hecht and Pienaar 1993). As reported in sea bass, size variation is a major cause of cannibalism (Katavic et al. 1989). Cannibalism is adopted by larvae and early juveniles due to genetic and behavioural causes. The latter depends on environmental factors i.e. food availability, turbidity, fish density and population size structure. Cannibalism has been observed in a large number of fish species (Hecht and Pienaar 1993). In cod, cannibalism may result in a daily loss of $1 \%$ of the population (Blom and Folkvord 1997). In aquaculture, regular fish sorting according to size improves population management because the rearing practices are better adapted to fish requirements (Smith and Reay 1991). Although it helps 
decrease cannibalism, sorting is questionable as regards experimental ecology purposes because it induces an artificial selection of fish which can alter the effects of studied factors. The management of fish size variability and its consequences in terms of the cannibalism and rearing practices of heterogeneous populations is a practical constraint as far as EEA is concerned. The feeding of fish having heterogeneous size is not well adapted to rearing practices because fish must be fed with food differing in size and composition. In such unfavourable conditions, cannibalism develops and it becomes impossible to control the experimental design. A larger variation in intra population results is observed whereby it is not possible to estimate the cause of the recorded effect. As a consequence, the effects of the studied factors can not be determined under these poor rearing conditions. On the other hand, the performances of fish reared in favourable conditions (rearing conditions providing high fish growth and survival) are better than those observed in the wild. In such conditions, the experimental design can be controlled and the interacting influences can be reduced. Therefore, experimental ecology protocols should not maintain fish in very unfavourable environmental conditions (providing low fish growth and survival).

Some fish species require a specific environment which may be difficult to mimic. For example, hydrostatic pressure is an essential signal in relieving gonadotropic blockage in the European eel (Anguilla anguilla) and triggering sexual maturation (Dufour and Fontaine 1985). Pressure is difficult to simulate in captivity. However, eels were maintained in freshwater at 100 atmospheric hydrostatic pressure, showing that it is possible to mimic environmental conditions at depth (Sébert et al. 1990). The experiment was short (one month) and the number of fish kept in experimental conditions remained limited. In addition, large-size migrating species such as bluefin tuna (Thunnus thynnus) require large volume cages ranging from 15000 to $200000 \mathrm{~m}^{3}$ (Doumenge 1999). This species was maintained in on-land facilities (Fores et al. 2000). Experiments conducted using this species require large volume facilities $\left(500 \mathrm{~m}^{3}\right)$ which are not readily available.

\subsection{Fish domestication}

Some fish species are difficult to adapt to captivity conditions. This is the case of hake because no rearing experiments are reported in this species. Among fish species which are candidates for rearing, it takes 1 to 5 years, depending on the species, to achieve a good level of zootechnical knowledge in order to produce sufficient quantities of juveniles (Muir and Young 1998). The duration of experimental ecology trials in the case of new species will be extended.

Domestication may also modify fish performances in captivity. Reared seventh-generation farmed salmon (Salmo salar) outgrew their wild counterparts, especially in salt water. By the end of the experiment, the former averaged three times the weight of the latter (Fleming et al. 2002). On the other hand, limited morphological and behavioural differences are observed between wild and hatchery reared cod (Svasand et al. 1998). In experimental ecology studies, highly domesticated fish whose behaviour and performances may differ from those of wild counterparts must not be used.

\subsection{Prevention of fish behaviour}

The prevention of some fish behaviours in captivity is a practical limit in the case of EEA. The process of migration is difficult to consider at the experimental scale. Like many other fish species, cod undertake foraging and spawning migrations over long distances. Vertical displacements also occur during 24-h periods in response to variations in temperature or prey availability. By preventing this behaviour in captivity, fish responses to experimental conditions may be affected. Furthermore, migrations could be induced by parameters of experimental interest such as water temperature: in Newfoundland between 1981 and 1992, the mean latitude of cod distribution shifted south by $200 \mathrm{~km}$ for each single degree decrease in the annual sea temperature (Rose et al. 1994). It was observed that the distribution of tropical fish extended northwards into the Euro-Atlantic sea waters due to ocean warming (Quéro 1998). Studying the effect of water temperature in captivity using a range test may induce additional migration requirements for values of this parameter poorly adapted to the studied species. Preventing this behaviour in captivity may modify the effect of studied factors. However, it is possible to examine how migrating fish adapt to the environmental conditions of new habitats using an experimental design. Furthermore, limited displacements may be recorded by EEA: the effect of temperature on cod position was studied, using a $6 \mathrm{~m}$ long horizontal thermal gradient tank. Fish position was mainly determined by temperature selection, the smaller fish choosing higher temperatures compared to larger cod (Lafrance et al. 2005).

\section{From tanks to the sea}

Rearing facilities cannot constitute the sea: this is the main shortcoming of EEA. The extrapolation of experimental results to the natural environment presents two problems: i) the realism of experimental design and ii) scaling.

\subsection{The realism of experimental design}

EEA simplifies natural complexity within an artificial situation with a controlled variation in a limited number of factors. It also reduces the confounding effects of the interacting factors because it lessens the uncontrolled part of the experimental design. Laboratory experiments carried out in order to assess optimal temperature for cod growth only considered water temperature as an experimental factor (Björnsson et al. 2000) but not covariation of other factors: a decrease by a factor of two of the mean size of copepods was attributed to increasing temperature in the North sea. This also reduced young cod survival (Beaugrand et al. 2003). Furthermore, specific artefact such as periphytic growth on container walls must be considered since it may account for over $50 \%$ of primary production assessed in mesocosms (Chen et al. 1997). This could affect the realism of the experimental design, or the extent to which this system mimics the natural ecosystem.

\subsection{Scaling}

Extrapolation is essential since experiments in ecology are carried out at a reduced scale. Ecologists are extremely interested in scaling i.e. extending the results of a study to larger 
scales. A host of publications has been devoted to the subject of scaling in ecology (for review see Kemp et al. 2001). Many ecological properties are "scale-sensitive". Scaling has two main dimensions, namely spatial and temporal. Fish larvae vulnerability to predation is inversely related to enclosure size (Paradis et al. 1996). Furthermore, fish growth rate depends on tank size (Theilbacker 1980). As suggested previously (paragraph 5.1), experimental ecology protocols should not maintain animals in unfavourable rearing conditions, i.e. limited volume tanks, since the confounding effects of interacting factors may not be avoided. The mean duration of 327 experiments in ecology was 29 days (Lodge et al. 1998). In short duration experiments, long term processes are not observed. Thus, the containment effect may vary with captivity duration (Frost et al. 2001).

The extrapolation of results recorded by EEA is related to the experimental scale. As suggested in the third part of this paper, two experimental scales can be used (Fig. 1): small volume controlled ecosystems and mesocosms. A study involving a single or limited number of factors can be performed in the first system, whereas complex interactions between parameters can be determined in the second one. A complete experimental study includes these two successive stages, the first one describing the precise effects of the studied factors and the second one rendering scaling easier. This is the case of a recent study conducted in sole (Solea solea) by Claireaux et al. (2004). It presented a combined study, assessing the effects of the Erika oil spill on the physiology and ecology of the common sole. This study included an experimental phase providing an assessment of fish kinetic contamination and mesocosm experiments determining the long-term effects of oil pollution on fish ecological performances. The association of a small scale study conducted in highly controlled facilities and a mesocosm experiment revealed functional alterations which could not be recorded in the wild: the experimental approach showed both reduced survival and growth three months after the contamination.

Regarding the temporal dimension, some scientific problems such as changes in age and size at first maturity require long period protocols. As these studies are aimed at determining the effects of individual juvenile history on first maturation and on reproductive performances over 2 or 3 consecutive years, they could take 5 to 6 years to complete in the case of cod.

A possible risk remains when scaling from experimental tanks to the natural ecosystem: Artefacts inherent in the experimental design may affect realism. It is difficult to mimic large natural ecosystems using tanks or mesocosms. Thus, ecological hypotheses can be better tested in a controlled environment by comparing results recorded at different levels of the studied factors. Therefore, EEA provides answers to ecological questions in the form of trends.

\section{Conclusion}

A combination of field studies and experimental ecology is required in order to better understand the ecological process. The former provides a description of the situation observed in the wild and can also suggest some possible causes of the observed phenomena. The latter presents an active investigation of these phenomena and it identifies their ultimate cause. Furthermore, a reliable quantification of the effects of the environmental factors can be assessed because of the large volume of data recorded in an experimental design.

EEA uses very different facilities ranging from laboratory microcosms to large ponds. The facilities must be adapted to experimental requirements: ranging from closely controlled small scale tank facilities which are used to assess the effects of a limited number of factors to large mesocoms testing the effects of several interacting factors. Whatever the experimental design, it cannot reproduce exactly the complexity of the marine ecosystem. As a consequence EEA improves the understanding of natural processes by providing answers to ecological questions in the form of trends. Compared to field studies, sampling capabilities are enhanced using EEA. Furthermore, an analytical platform can be set up in a laboratory allowing an in depth description of physiological mechanisms in fish.

EEA is a pluri-disciplinary activity involving interactions between different domains. The study of the effects of environmental parameters in fish requires close cooperation between fishery scientists, ecologists, aquaculturists, physiologists and geneticists. This approach is essential to the grasp of the complex process observed in the wild.

Finally, EEA works on the understanding of a current key problem: the human impact on the natural ecosystem. EEA can play an important role in describing the effects of the non sustainable use of resources, global warming, pollution and loss of natural habitats. For all these reasons, EEA must be considered as a key to understanding fish biology in the wild.

Acknowledgements. This work was presented at the International Symposium of the Fisheries Society of the British Isles (London, 1923 July 2004). The authors want to thank two anonymous referees for their constructive remarks.

\section{References}

Aas E., Baussant T., Balk L., Liewenborg B., Andersen O.K., 2000, PAH metabolites in bile, cytochrome P4501A and DNA adducts as environmental risk parameters for chronic oil exposure: a laboratory experiment with Atlantic cod. Aquat. Toxicol. 51, 241-258.

Adoff G., Skjennum F.C., Engelsen R., 2002, Experience and prospects of Norwegian cod farming. Bull. Aquac. Assoc. Can. 102, 8-11.

Babiak I., Brzuska E., Perkowski J., 2000, Fractional factorial design of screening experiments on cryopreservation of fish sperm. Aquac. Res. 31, 273-282.

Beaugrand G., Brander K., Lindley J.A., Souissi S., Reid P.C., 2003, Plankton effect on cod recruitment in the North sea. Nature 426, 661-664.

Bégout Anras M.L., Lagardère J.P., 1998, Variabilité météorologique et hydrologique. Conséquences sur l'activité natatoire d'un poisson marin. C.R. Acad. Sci. Paris 321, 641-648.

Björnsson B., Steinarsson A., 2002, The food-unlimited growth rate of Atlantic cod (Gadus morhua). Can. J. Fish. Aquat. Sci. 59, 494-502. 
Björnsson B., Steinarsson A., Oddgeirsson, M., 2001, Optimal temperature for growth and feed conversion of immature cod (Gadus morhua L.). ICES J. Mar. Sci. 58, 29-38.

Blom G., Folkvord A., 1997, A snapshot of cannibalism in 0-group Atlantic cod (Gadus morhua) in a marine pond. J. Appl. Ichthyol. 13, 177-181.

Brander K., 1996, Effects of climate changes on cod (Gadus morhua) stocks. In: Wood C.M., Mc Donald D.G.(Eds.), Global warming: Implications for freshwater and marine fish. University Press: Soc. Exp. Biol. Seminar Ser. 61, 255-278.

Castilla J.C., 2000, Roles of experimental marine ecology in coastal management and conservation. J. Exp. Mar. Biol. Ecol. 250, 3-21.

Chambers R.C., Waiwood K.G., 1996, Maternal and seasonal differences in egg sizes and spawning characteristics of captive Atlantic cod, Gadus morhua. Can. J. Fish. Aquat. Sci. 53, 1986-2003.

Chen C.C., Petersen J.E., Kemp W.M., 1997, Spatial and temporal scaling of periphyton growth on walls of estuarine mesocosms. Mar. Ecol. Progr. Ser. 155, 1-15.

Claireaux G., Désaunay Y., Akcha F., Aupérin B., Bocquené G., Budzinski H., Cravedi J.P., Davoodi F., Galois R., Gilliers C., Goanvec C., Guérault D., Imbert N., Mazéas O., Nonnotte G., Nonnotte L., Prunet P., Sébert P., Vettier A., 2004, Influence of oil exposure on the physiology and ecology of the common sole Solea solea: Experimental and field approaches. Aquat. Living Resour. 17, 335-351.

Clemmesen C., Buehler V., Carvalho G., Case R., Evans G., Hauser, L., Hutchinson W.F., Kjesbu O.S., Mempel H., Moksness E., Otteraa H., Paulsen H., Thorsen A., Svaasand T., 2003, Variability in condition and growth of Atlantic cod larvae and juveniles reared in mesocosms: environmental and maternal effects. J. Fish Biol. 62, 706-723.

De Pontual H., Bertignac M., Battaglia A., Bavouzet G., Moguedet P., Groison A.L., 2003, A pilot tagging experiment on European hake (Merluccius merluccius): methodology and preliminary results. ICES J. Mar. Sci. 60, 1318-1327.

Devauchelle N., 2002, Assessing the health of marine organisms and ecosystems. Which biological signals should be measured? IFREMER Plouzané.

Divanach P., Kentouri M., 2000, Hatchery techniques for specific diversification in Mediterranean finfish larviculture. Cah. Options Méditerr. 47, 75-89.

Doumenge F., 1999, L'aquaculture des thons rouges et son développement économique. Biol. Maric. Méditerr. 6, 107-148.

Dufour S., Fontaine, Y.A., 1985, The reproductive migration of the European eel (Anguilla anguilla): The probable importance of hydrostatic pressure in stimulation of the gonadotropic function. Bull. Soc. Zool. France 110, 291-300.

Ellis T., North B., Scott A.P., Bromage N.R., Porter M., Gadd, D., 2002, The relationships between stocking density and welfare in farmed rainbow trout. J. Fish Biol. 61, 493-531.

FAO, 2001, http://www . fao.org/fi/statst/FISOFT/fishplusf.asp.

Fleming I.A., Agustsson T., Finstad B., Johnsson J.I., Bjornsson B.T., 2002, Effects of domestication on growth physiology and endocrinology of Atlantic salmon (Salmo salar). Can. J. Fish. Aquat. Sci. 59, 1323-130.

Fores R., Samper M., Cejas J.R., Santamaria F.J., Villamandos J.E, Jerez S., 2000, Acclimatization of tuna fish to on-land facilities. Cah. Options Méditerr. 47, 287-294.

Frost T.M., Ulanowicz R.E., Blumenshine S.C., Allen T.F.H., Taub F., Rodgers J.H. Jr, 2001, Scaling issues in experimental ecology. In: Gardner R.H., Kemp W.M., Kennedy V.S., Petersen J.E. (Eds.),
Scaling relations in experimental ecology, New York, Columbia University Press, pp. 253-279.

Hecht, T., Pienaar A., 1993, A review of cannibalism and its implications in fish larviculture. J. World Aquac. Soc. 24, 246-261.

Hegerl G., Bindoff N., 2005, Warming the world's oceans. Science 309, 254-255.

Imsland A.K., Jonsdottir O.D.B., 2002, Is there a genetic basis to growth in Atlantic cod? Fish Fish. 3, 36-52.

Isaksson I., Pihl L., Van Montfrans, J., 1994, Eutrophication-related changes in macrovegetation and foraging of young cod (Gadus morhua L.): a mesocosm experiment. J. Exp. Mar. Biol. Ecol. 177, 203-217.

Katavic I., Jugdujakovic J., Glamuzina B., 1989, Cannibalism as a factor affecting the survival of intensively cultured sea bass (Dicentrarchus labrax) fingerlings. Aquaculture 77, 135-143.

Kellison G.T., Eggleston D.B., Taylor J.C., Burke J.S., Osborne J.A., 2003, Pilot evaluation of summer flounder stock enhancement potential using experimental ecology. Mar. Ecol. Prog. Ser. 250, 263-278.

Kemp W.M., Petersen J.E., Gardner R.H., 2001, Scale dependence and the problem of extrapolation. In: Gardner R.H., Kemp W.M., Kennedy V.S., Petersen J.E. (Eds.), Scaling relations in experimental ecology. New York, Columbia University Press, pp. 3-57.

Kjesbu O.S., 1989, The spawning activity of cod, Gadus morhua L. J. Fish Biol. 34, 195-206.

Kobilinsky A., 1997, Les plans factoriels. In: Droebeke J.J., Fine J. (Eds.), Plans d'expérience, applications à l'entreprise, Technip, Paris.

Lafrance P., Castonguay M., Chabot D., Audet C., 2005, Ontogenic changes in temperature preference of Atlantic cod. J. Fish Biol. 66, 553-567.

Lambert Y., Dutil J.D., 1997, Condition and energy reserves of Atlantic cod (Gadus morhua) during the collapse of the northern Gulf of St Lawrence stock. Can. J. Fish. Aquat. Sci. 54, 2388-2400.

Lambert Y., Dutil J.D., 2000, Energetic consequences of reproduction in Atlantic cod (Gadus morhua) in relation to spawning level of somatic energy reserves. Can. J. Fish. Aquat. Sci. 57, 815-825.

Lambert Y., Dutil J.D., 2001, Food intake and growth of adult Atlantic cod (Gadus morhua L.) reared under different conditions of stocking density, feeding frequency and size grading. Aquaculture 192, 233-247.

Lawton J.H., 1995, Ecological experiments with model systems. Science 269, 328-331.

Lesser M.P., 2004, Experimental biology of coral reef ecosystems. J. Exp. Biol. Ecol. 300, 217-252.

Lodge D.M., Blumenshine S.C., Vadeboncouer Y., 1998, Insights and application of large-scale, long-term ecological observations and experiments. In: Resetarits W.J., Bernardo J. (Eds.), Experimental ecology: Issues and perspectives, Oxford University Press, Oxford, pp. 202-235.

Marteinsdottir G., Begg G.A., 2002, Essential relationships incorporating the influence of age, size and condition on variables required for estimation of reproductive potential in Atlantic cod Gadus morhua. Mar. Ecol. Prog. Ser. 235, 235-256.

Morgan M.J., Wilson C.E., Crim L.W., 1999, The effect of stress on reproduction in Atlantic cod. J. Fish Biol. 54, 477-488.

Muir J.F., Young J.A., 1998, Strategic issues in new species development for aquaculture. In: Enne G., Greppi G.F. (eds). New species for Mediterranean aquaculture. Elsevier, pp. 22-24.

Nilssen E.M., Pedersen T., Hopkins C.C.E., Thyholt K., Pope J.G., 1994, Recruitment variability and growth of Northeast Arctic cod: Influence of physical environment, demography, and predator-prey energetics. ICES Mar. Sci. Symp. 198, 449-470. 
Nissling A., 1994, Survival of eggs and yolk-sac larvae of Baltic cod (Gadus morhua L.) at low oxygen in different salinities. ICES Mar. Sci. Symp. 198, 626-631.

Ojeda F.P., Dearborn J.H., 1991, Feeding ecology of benthic mobile predators: experimental analyses of their influence in rocky subtidal communities of the Gulf of Maine. J. Exp. Mar. Biol. Ecol. $149,13-44$.

Omnes M.H., Sévère A., Barone H., Suquet M., Buchet V., Le Roux A., Gaignon J.L., Fostier A., Fauvel C., 2002, Growth and reproductive performances of juveniles and sexually mature pollack Pollachius pollachius in different conditions. EAS Spec. Publ. 32, 394-395.

Otterlei E., Nyhammer G., Folkvord A., Stefansson S., 1999, Temperature and size-dependent growth of larval and early juvenile Atlantic cod (Gadus morhua): a comparative study of Norwegian coastal cod and northeast Arctic cod. Can. J. Fish. Aquat. Sci. 56, 2099-2111.

Paradis A.R., Pepin P., Brown J.A., 1996, Vulnerability of fish eggs and larvae to predation: Review of the influence of the relative size of prey and predator. Can. J. Fish. Aquat. Sci. 53, 1226-1235.

Pickova J., Larsson P.O., Kiessling A., 2000, Possible explanations to Baltic cod reproduction problems- a short review. In: Norberg B., Kjesbu O.S., Taranger G.L., Andersson E., Stefansson S.O. (Eds.), Proc. 6th Int. Symp. Reprod. Physiol. Fish, Bergen, pp. 92-94.

Pitta P., Giannakourou A., Divanach P., Kentouri M., 1997, Planktonic food web in marine mesocosms in the Eastern Mediterranean. Bottom-up or top-down regulation. Hydrobiologia 363, 97-105

Planque B., Beillois P., Jégou A.M., Lazure P., Petitgas P., Puillat I., 2003, Large-scale hydroclimatic variability in the Bay of Biscay: the 1990s in the context of interdecadal changes. ICES Mar. Sci. Symp. 219, 61-70.

Purchase C.F., Brown J.A., 2000, Interpopulation differences in growth rates and food conversion efficiencies of young Grand Banks and Gulf of Maine Atlantic cod (Gadus morhua). Can. J. Fish. Aquat. Sci. 57, 2223-2229.

Quéméner L., Suquet M., Mero D., Gaignon J.L., 2002, Selection method of new candidates for finfish aquaculture: the case of the French Atlantic, the Channel and the North Sea coasts. Aquat. Living Resour. 15, 293-302.

Quéro J.C., 1998, Changes in the Euro-Atlantic fish species composition resulting from fishing and ocean warming. Ital. J. Zool. 65, 493-499.

Rochet M.J., 2000, A comparative approach to life-history strategies and tactics among four orders of teleost fish. ICES J. Mar. Sci. 57, 228-239.

Rochet M.J., Cornillon P.A., Sabatier R., Pontier D., 2000, Comparative analysis of phylogenetic and fishing effects in life history patterns of teleost fishes. Oikos 91, 255-270.

Rose G.A., Atkinson B.A., Baird J., Bishop C.A., Kulka D.W., 1994, Changes in distribution of Atlantic cod and thermal variations in Newfoundland waters, 1980-1992. ICES Mar. Sci. Symp. 198, $542-552$.

Rowe S., Hutching J.A., Bekkevold D., Rakitin A., 2004, Depensation, probability of fertilization, and the mating system of Atlantic cod (Gadus morhua L.). ICES J. Mar. Sci. 61, 1144-1150.
Sébert P., Barthélémy L., Simon B., 1990, Laboratory system enabling long-term exposure $(>30 \mathrm{~d})$ to hydrostatic pressure $(<101 \mathrm{~atm})$ of fishes or other animals breathing water. Mar. Biol. 104, 165-168.

Smith C., Reay P., 1991, Cannibalism in teleost fish. Rev. Fish Biol. Fish. 1, 41-64.

Spies, A., Parsons T.R., 1985, Estuarine microplankton: an experimental approach in combination with field studies. J. Exp. Mar. Biol. Ecol. 92, 63-81.

Sundby S., Ellertsen B., Fossum P., 1994, Encounter rates between first-feeding cod larvae and their prey during moderate to strong turbulent mixing. ICES Mar. Sci. Symp. 198, 393-405.

Suquet M., Normant Y., Sevère A., Barone H., Fostier A., Le Delliou H., Fauvel C., 2001, Growth performance of the wreckfish (Polyprion americanus) in captivity. EAS Spec. Publ. 30, 586-589.

Suquet M., Normant Y., Gaignon J.L., Quéméner L., Fauvel C., 2005, Effect of water temperature on individual reproductive activity of pollack (Pollachius pollachius). Aquaculture 243, 113-120.

Svasand T., Skilbrei O.T., Van der Meeren G.I., Holm M., 1998, Review of morphological and behavioural differences between reared and wild individuals: implications for sea-ranching of Atlantic salmon, Salmo salar L., Atlantic cod, Gadus morhua L., and European lobster, Homarus gammarus L. Fish. Manage. Ecol. 5, 473-490.

Theilacker G.H., 1980, Rearing containers size affects morphology and nutritional condition of larval jack mackerel, Trachurus symmetricus. Fish. Bull. 78, 789-791.

Tsou,T.S., Collie J.S., 2001, Estimating predation mortality in the Georges Bank fish community. Can. J. Fish. Aquat. Sci. 58, 908-922.

Underwood A.J., 1996, Detection, interpretation, prediction and management of environmental disturbances: some roles for experimental marine ecology. J. Exp. Mar. Biol. Ecol. 200, 1-27.

Underwood A.J., 2000, Experimental ecology of rocky interdidal habitats: what are we learning? J. Exp. Mar. Biol. Ecol. 250, 51-76.

Van Der Kraak G., Pankhurst N.W., 1996, Temperature effects on the reproductive performance of fish. In: Wood C.M., Mc Donald D.G (Eds.) Global warming: Implications for freshwater and marine fish. University Press: Soc. Exp. Biol. Seminar Ser. 61, 159-176.

Van Dover C.L., Lutz R.A., 2004, Experimental ecology at deepsea hydrothermal vents: a perspective. J. Exp. Biol.Ecol. 300, 273-307.

Whale R.A., 2003, Revealing stock-recruitment relationships in lobsters and crabs: is experimental ecology the key? Fish. Res. 65, 3-32.

Wroblewski J.S., Hiscock H.W., Bradbury I.R., 1999, Fecundity of Atlantic cod (Gadus morhua) farmed for stock enhancement in Newfoundland bays. Aquaculture 171, 163-180.

Ylönen H., Wolff J.O., 1999, Experiments in behavioural ecology and the real world. Trends Ecol. Evol. 14, 82. 